\title{
Comparison of Public Risk Management Tools in Slovak Agriculture
}

\author{
Andrea Boháčiková ${ }^{1, *}$, Tatiana Bencová ${ }^{1}$, and Tomáš Rábek ${ }^{1}$ \\ ${ }^{1}$ Slovak University of Agriculture in Nitra, Faculty of Economics and Management, Department of \\ Finance, Tr. A. Hlinku 2, 94976 Nitra, Slovakia
}

\begin{abstract}
.
Research background: Risk in agriculture is a difficult concept to recognize, because farmers are exposed to different types of risks that influence their agricultural activity. The stability of farmer's income is threatened by various factor interconnected to each other, such as market risks (price volatility, market shocks), financial risks (indebtedness, loans and credits), production risks (climate change, pests and diseases, biosecurity), technological risk (digitization, technological progress), institutional risk (regulations, environment and tax policy), and human resource risk (physical and mental health). Therefore, for the farmers it is very challenging to implement appropriate and effective risk management tools, in order to stabilize their income.

Purpose of the article: Risk management offers a variety of strategies and instruments on the farm or aggregate level to copy with the risk. Also in the Pillar II of CAP 2014-2020 were introduced new risk management tools, as a response to greater price and yield variability among European countries. In the paper, we decided to analyse and compare several public risk management tools that can farmers use to increase their welfare and stabilize income.

Methods: The national agricultural policies, as well as CAP are aimed at compensating farmers for the negative effects, however it is not so easy to govern and implement the tools on the farm level. The paper provides a comparative analysis of selected tools that are the most suitable for Slovak agricultural producers.

Findings \& Value added: The results of the paper can give the farmers ability to compare and choose between public risk management tools that could be used for risk exposure.
\end{abstract}

Keywords: risk management tools; agriculture; income stabilization; CAP

JEL Classification: $Q 14 ; Q 18 ; G 32$

\footnotetext{
${ }^{*}$ Corresponding author: andrea.bohacik@gmail.com
} 


\section{Introduction}

Managing risk in farming is basically aimed at stabilizing the farmers' income situation, reducing the negative consequences of adverse events, and preventing farmers from potential threats; individual or market. Farmers vary in their ability to address risky situations or their attitude to risk, therefore the process of risk management cannot be viewed within a "one size fits all" approach. Also it is not possible to avoid risk at all, rather finding the best available combination of risk and return given a person's capacity to undergo a wide range of outcomes [1]. Several risk management strategies and tools are offered for the farmers to mitigate and prevent the risks in general.

The effective risk management involves four main steps, as identifying potential sources of risk (price, pests, yield, labour), anticipating the probability of possible outcomes and their consequences (low income, crop and livestock production), taking actions to obtain a preferred combination of risk and expected return / decide a strategy available (packaging, pest control, production plan, new technology), and implementing future risk-planning strategies, after distress conditions have passed [1-3]. Often the problem of farmers is, that they do not involve the risk management approach as planning a strategy in advance, but just react to events after they occur.

Managing risk starts usually at the farm level (micro), where farmers have large variety of options in order to reduce their exposure to risks. They can diversify agricultural production (horizontal and vertical diversification), adopt on-farm practices such as the use of more resilient crops/animals, reinforced sanitary measures, locally adapt agricultural practices, agroturism, appropriate preventive investments (anti-hail nets or sustainable irrigation), or use the private-based insurance of crops, livestock and property. The business activities can also be prevented by using contracts, financial derivatives and hedging $[4,5]$. The applied analysis of tools at the farm level can be found in the studies of [4, 6-8]. Public support for these tools can indirectly be through education, training and reducing information asymmetry $[3,5]$.

On the macro level the risk management in agriculture includes basically the policy decisions to reinforce farmers' resilience, maintain safety nets for dealing with natural disasters and stabilise agricultural income [7]. In the CAP, risk management instruments have become more important over the time. Since 1998, the European Community has been intensively investigating the possibilities of how to assist farmers in stabilizing their incomes [9]. After the Health Check 2008, risk management proposal was introduced for the first time, with the risk instruments such as subsidised insurance schemes and mutual funds in the operational programmes for the fruits, vegetables and wine sector. Number of improvements was suggested during the testing period [7], which led to the newly introduced support for risk management, after the 2013 CAP reform. Since the CAP programme 2014-2020 the farmers support is funded under two pillars. Under Pillar I, the EU finances commodity programs to stabilize markets against major price disturbances. It means market measures, risk management and crisis prevention measures for some sectors (wine, fruit and vegetables) and exceptional measures [13]. Under Pillar II, the EU gives Member States the possibility of supporting three risk management instruments: insurance premiums, mutual fund and income stabilisation tool (IST) [10-14]. Unfortunately, the CAP risk management abilities have remained at the theoretical level in majority of European countries. There are doubts in the agricultural sector whether the new EU's CAP is capable of coping with market disruption [5]. Therefore, the CAP reform after 2020 faces challenges with the risk management implementation on the national level, with the appropriate guidance and costs reduction. The main aim of the paper is to evaluate the existing risk management tools of CAP, and the use of public risk management tools in the Slovak agriculture. 


\section{Material and Methods}

There are many risks in agriculture (market, production, financial, institutional, human, technological, etc.), that are basically interconnected to each other, commonly affecting the income volatility of farmers. Income from farming refers to the sum of revenues the farmer receives from the market, including any form of public support, deducting input costs [15]. Income risks mitigation represents one of the key objectives of CAP risk measures, as it not only reflects the income volatility, but also refers to low levels of income, that can result in cash-flow constraints and lead to farmers' bankrupt. In the paper, we evaluate and critically look at the CAP risk management tools.

The methods for identifying possible positive and negative impacts of agricultural risk management tools respect the holistic approach. In the holistic approach the risks are divided into normal, marketable and catastrophic (Fig. 1). To each risk category belongs the different risk management strategy that should be used for effective mitigation [3]. In the paper we compare and evaluate three public risk management tools from the Pilar II of CAP 2014 - 2020; insurance premium, mutual funds and Income stabilisation tool. The data for comparison are mainly obtained from the studies of $[10,11,13,16,17]$. Moreover, we examine and evaluate the use of public risk management tools in Slovak agriculture. The data for the analysis are obtained from the Ministry of Agriculture and Rural Development of Slovak republic, and Agricultural Paying Agency.

Table 1. Risk management tools, holistic approach

\begin{tabular}{|c|l|c|c|}
\hline Type of risk & Characteristic & Risk management tools & Classification \\
\hline Normal & $\begin{array}{c}\text { Occurs frequently, } \\
\text { with low damages }\end{array}$ & $\begin{array}{c}\text { Financial management } \\
\text { Savings } \\
\text { Standards (quality) } \\
\text { Diversification }\end{array}$ & $\begin{array}{c}\text { ON FARM } \\
\text { strategies }\end{array}$ \\
\hline Marketable & $\begin{array}{c}\text { Less frequent, but } \\
\text { with higher losses }\end{array}$ & $\begin{array}{c}\text { Futures } \\
\text { Private insurance } \\
\text { Non-subsidised mutual funds }\end{array}$ & $\begin{array}{c}\text { MARKET } \\
\text { TOOLS }\end{array}$ \\
\hline Catastrophic & $\begin{array}{c}\text { Rare, but with high } \\
\text { damage and } \\
\text { systematic character }\end{array}$ & $\begin{array}{c}\text { Insurance premium } \\
\text { Mutual funds } \\
\text { Income Stabilisation Tool } \\
\text { CAP market measures } \\
\text { Ad hoc disaster aid }\end{array}$ & $\begin{array}{c}\text { EX ANTE and } \\
\text { EX POST } \\
\text { policies }\end{array}$ \\
\hline
\end{tabular}

Source: OECD (2011), own processing

\section{Results and discussion}

The actual risk management tools for agricultural producers are defined in the CAP 2014 2020 under the Pilar II in the Regulation (EU) n $1305 / 201$, Article $36-39$. The Member States, including Slovak republic, are allowed to allocate funds of the European Agricultural Fund for Rural Development (EAFRD) to provide financial contribution to income stabilisation by: subsidies for insurance (Art. 37); for mutual funds compensating production losses (Art. 38); and for the Income Stabilisation Tool (IST). IST consists of mutual funds compensating income losses due to production or price risks (Art. 39). Despite the abilities for EU countries to cover large variety of risks, the EU toolkit proposed in the regulations has been largely underutilised [19]. In to following part we take a critical look at the CAP risk management tools and their use. 


\subsection{Insurance premiums of CAP}

In the period 2009-2013, member states were allowed to support insurance premiums using the direct payments "envelopes" up to $10 \%$. In the next programming period, insurance support has become a part of the second pillar for the period 2014-2020 with premium being allowed for animal and plant insurance [13]. Support shall only be granted for insurance contracts, which cover for loss caused by an adverse climatic event, by an animal or plant disease, a pest infestation, an environmental incident or a measure adopted in accordance with Directive 2000/29/EC to eradicate or contain a plant disease, or pest which destroys the average annual production of the farmer [18]. The Member States might allocate the insurance premiums up to $65 \%$, under the condition that the losses represent more than $30 \%$ of the average annual production of the farmer, based on a three-year average or an "Olympic" average [7]. Since 2018 the loss thresholds have been reduced to $20 \%$ and the allowed support rate has increased to $70 \%$ [20].

Currently, almost 2.7 billion $€$ have been allocated on risk management tools, from which insurance premiums are projected to 2.2 billion EUR, the mutual funds to 357 million $€$, and 130 million $€$ for the Income Stabilisation Tool. The share of the CAP budget spent on risk management is still very low, as it represents only $2 \%$ of the Pillar II budget and $0.4 \%$ of the total CAP budget for the 2014-2020 period [19].

In comparison with other tools, the insurance premium has been the most successful in implementation. Countries using this tool are Belgium (Flanders), France, Hungary, Italy, Croatia, Malta, Latvia, Lithuania, the Netherlands and Portugal. In insurance programme varies across the EU countries. In France, Spain and Italy are the best developed insurance programmes for climatic risks [21]. In Hungary and Poland crop insurance is partly obligatory. Hungarian farmers are obliged to buy insurance, if their farm is larger than 10 ha (arable farms) or 5 ha (vegetable farms). In Poland, farmers have to buy insurance at least for half of their utilised agricultural area, if they receive direct payments [13, 22]. Main obstacles of the insurance are the high premiums (especially for multi-peril insurance), high loss threshold to trigger compensation (30\%) and lack of farm-level data and information, leading to information asymmetry. In the post-2020 several changes are expected in connection to the risk management programme.

\subsection{Mutual funds}

The mutual fund is a financial reserve from annual farmers' contributions that are regulated by each country. In the case of adverse event the farmer's loss is compensated. The difference compared to insurance is that mutual funds require farmers' collective engagement and common ownership (no risk transfer to private party). Financial contribution to mutual funds in CAP is stated under Article 38 of the Rural Development Regulation for climatic or sanitary risks, and under Article 39 for severe drops in income, that latter changed to individual risk management tool, the Income stabilisation tool. Similarly, as in the other risk management tools, the condition is that fund covers production loss caused by the outbreak of adverse climatic events, an animal or plant disease, a pest infestation, or an environmental incident, which destroy more than $30 \%$ of the average annual production of the farmer in the preceding three-year period or a fiveyears Olympic average (excluding the highest and lowest entry). The compensatory payments may benefit from a public financial contribution limited to a maximum $65 \%$. Member States shall define the rules for the constitution and management of the mutual funds, in particular for the granting of compensation payments and the eligibility of farmers 
in the event of crisis, as well as for the administration and monitoring of compliance with these rules [18].

With the Agricultural Omnibus, the threshold for compensation has been lowered from $30 \%$ to $20 \%$, while the financial rate support has been increased from $65 \%$ to $70 \%$. In addition, annual payments into mutual funds and their initial capital stock became eligible, as well as extended possibilities to use indexes [20]. The Regulation allows the subsidising of 'administrative costs of setting up the mutual fund' and 'the amounts paid by the mutual fund as financial compensation'.

The initiative to develop the mutual funds within the Rural Development programmes for the period 2014-2020 had 3 countries (FR, IT, RO). France has budgeted $€ 60$ million for the FMSE, Italy $€ 97$ million, and Romania $€ 200$ million. Finally, the only country, which really operated a mutual fund as regulated by Art. 38, has been France. In 2012, the Fonds national agricole de Mutualisa-tion Sanitaire et Environnementale (FMSE), was created and limited to adverse sanitary and environmental events, to provide a national fund that merged local mutual funds developed for livestock producers [10]. The true is, there exist Mutual funds also in other European countries f. e. Italy, Netherlands or Romania, however these countries do not use the ability of EU subsidisation under Art. 38. Often the problem is, that there has been a lack of leadership in the farmers' unions, and a lack of cooperation between the Ministry of Agriculture and the farmers' unions [7].

\subsection{Income Stabilisation Tool}

The Income Stabilisation Tool is basically a mutual fund that compensates for income losses (not production losses) for less than $70 \%$ indemnification, when the actual loss is greater than a $30 \%$ compared to a 3-years average or Olympic average, computed from historical income. The principal should be that farmers contribute to the mutual fund to establish a financial reserve that can be used to compensate farmers for income losses independent of the cause. Furthermore, the members of the fund obtain financial support from EU.

Three member states have planned to implement an Income Stabilisation Tool: Spain in the region of Castilla et Leon, Hungary and Italy. Unfortunately, none of the mentioned countries has been using this tool operationally [19]. In Spain, the problem occurred to use IST concerned to specialised dairy producers, and with the practical measurement of income. In Hungary a great focus has been to implement IST, but the lack of guidelines, experience and knowledge caused that it has not been developed so far. In Italy, there have been difficulties to monitor the historical income of farmers, as well as the $30 \%$ level of the threshold, which was considered to be high $[10,23]$. Positive is that EU shows the effort to implement to IST, and reacts to the needs of member states in Omnibus regulation 2018 and the CAP post-2020 initiative.

A sector-specific IST has been added to the toolkit, targeting farmers of a specific sector, which can be used by a drop of exceeding $20 \%$ of average annual income (lower from $30 \%$ ). The indexes may be used to calculate the annual loss of income of the farmer (both general and sector-specific ISTs). The compensation rate stayed at $70 \%$.

\subsection{Critical points of risk management tools}

The main criticism of public risk management tools of CAP 2014-2020 says that the tools are more suggestions (optional for Member States), rather than effective programs. Except for the insurance premiums used in several countries, the risk management tools under Pilar II remain at the theoretical level, not operational. 
Obstacles connected with the insurance are mainly the high premiums (especially for multi-peril insurance), high loss threshold (since 2018 lowered to 20\% from $30 \%$ ) and lack of farm-level data and information, leading to information asymmetry.

There is a need for more efficient guidelines, especially for Mutual Funds and sectoral Income Stabilisation Tools. The lack of any significant experience in European or other countries outside the EU makes it difficult to accept the Mutual funds and IST, and develop them to national policies. It is necessary to create a public platform to share experiences which could potentially build common benchmarks. The other problem of IST seems to be the difficulties in monitoring the historical income of farmers (lack of income data on individual farm level). Even if the monitoring is successful, the choice of income variable for examination remains questionable. Potential problem might be the willingness of farmers to cooperate, as it is not traditional in number of Member States. It implies lack of solidarity and limited capital availability, especially in the start-up phase [7]. There is a lack of leadership in the farmers' unions, and usually ineffective co-operation between the Ministry of Agriculture and the farmers' unions. There raises also the question of potential double compensation, if farmers use two instruments at once. Potential threat is the ability of farmers to adjust accounting records in order to obtain IST premium. Important issue is also the education of farmers in the context of risk management that is directly connected with the willingness to implement risk management tools.

Table 2. Evaluation of risk management tools.

\begin{tabular}{|c|c|c|c|}
\hline $\begin{array}{c}\text { Risk management } \\
\text { tool }\end{array}$ & Insurance & Mutual funds & $\begin{array}{c}\begin{array}{c}\text { Income stabilisation } \\
\text { tool }\end{array} \\
\end{array}$ \\
\hline Risk coverage & $\begin{array}{c}\text { production loss of } \\
\text { adverse climatic event, } \\
\text { animal or plant } \\
\text { disease, pest } \\
\text { infestation, } \\
\text { environmental } \\
\text { incident higher than } \\
30 \% \text { (changed to } \\
20 \% \text { ) }\end{array}$ & $\begin{array}{l}\text { production losses due } \\
\text { to climatic, sanitary } \\
\text { and environmental } \\
\text { risks higher than } 30 \% \\
\text { (changed to } 20 \% \text { ) }\end{array}$ & $\begin{array}{l}\text { drop of the average } \\
\text { annual income of the } \\
\text { individual farmer } \\
\text { higher than } 30 \% \\
\text { (changed to } 20 \% \text { ) }\end{array}$ \\
\hline \multirow{3}{*}{ Critical points } & $\begin{array}{l}\text { High systematic risk } \\
\text { Demand for re- } \\
\text { insurance }\end{array}$ & $\begin{array}{l}\text { Low financial } \\
\text { contribution } 65 \% \\
\text { (changed to } 70 \% \text { ) } \\
\text { lack of leadership in } \\
\text { the farmers' unions }\end{array}$ & $\begin{array}{l}\text { Income variable } \\
\text { choice } \\
\text { No sectoral IST }\end{array}$ \\
\hline & & \multicolumn{2}{|c|}{$\begin{array}{c}\text { Insufficient guidelines, lack of experience } \\
\text { No interest of farmers to cooperate and } \\
\text { contribute to funds } \\
\text { Potential negligence of farmer (information } \\
\text { misuse) }\end{array}$} \\
\hline & \multicolumn{3}{|c|}{$\begin{array}{c}\text { Insufficient monitoring and data, } \\
\text { Information asymmetry } \\
\text { High level of thresholds (lowered to } 20 \% \text { ) } \\
\text { Low awareness of farmers at national level }\end{array}$} \\
\hline Implementation & $\begin{array}{l}\text { Belgium (Flanders), } \\
\text { France, Hungary, } \\
\text { Italy, Croatia, Malta, } \\
\text { Latvia, Lithuania, the } \\
\text { Netherlands and } \\
\text { Portugal }\end{array}$ & $\begin{array}{c}\text { France } \\
\text { (planned in Italy, } \\
\text { Romania) }\end{array}$ & $\begin{array}{l}\text { No countries } \\
\text { (planned in Castilla et } \\
\text { Leon, Hungary and } \\
\text { Italy) }\end{array}$ \\
\hline
\end{tabular}

Source: own processing 


\subsection{Risk management is Slovakia}

The risk management tools of CAP are available for Slovak agricultural producers, however none has been implemented in the Slovak Rural Development Programme. To deal with agricultural risks the Slovak farmers have ability to use:

- commercial insurance of crops, animals and property,

- support of insurance for selected crops - vineyards,

- Ad-hoc government measures from the state budget - in the case of excessive catastrophic damage, not covered by commercial insurance.

Insurance of agricultural production is provided by 3 commercial insurance companies: Allianz - Slovenská Poist'ovňa, a. s. (approximately 60\% market share), Generali Slovensko Poist'ovňa, a. s. (around 18\%), UNIQA Poist'ovňa, a.s. (12\%) and one Austrian insurance branch (AGRA poist'ovňa - Die Österreichische Hagelversicherung VVaG). The supply of insurance products is limited, because private insurance companies are not able to insure all risks [24].

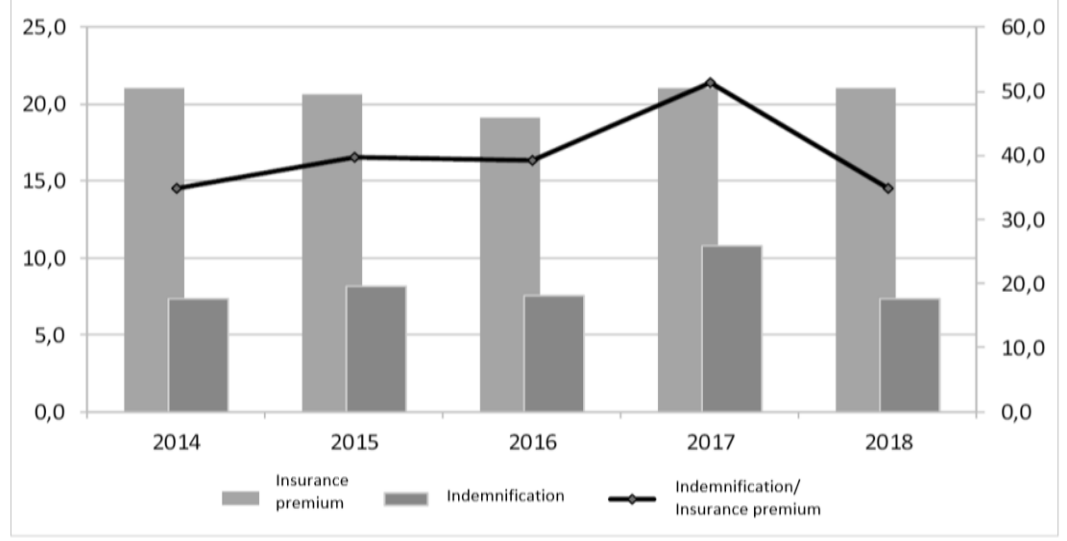

Fig. 1. Insurance in Slovak Agriculture

Source: Green report 2018 (Ministry of Agriculture and Rural Development), added by authors

In 2018, agricultural companies insured property, crops and animals in commercial insurance companies in the total amount of 21.033 mil. $€$, from which almost $35 \%$ of damages were covered [25]. The majority of insurance premiums covered the property insurance in the amount of 13.5 mil. $€(64 \%)$. Farmers insured their crops 2.3 times less than property, only $28 \%$ (almost 6 mill. $€$ ). From the overall insurance payed, animal insurance represented only $8 \%$ ( 1.6 mil $€)$, which is even 3.6 times less than crops. The compensation for claims was at the level of $43 \%$ in property insurance, $25 \%$ in crop insurance, and only $6 \%$ in animal insurance. The commercial insurance companies offered in 2018 also the preventive risk measures for farmers. In the long run, crop and animal insurance is declining and property insurance is rising.

The damages caused by uninsurable risks are compensated by ad hoc state aid. The additional support from the state is regulated by the State Aid Act 358/2015 Coll. $\S 8$, in which the rules for providing "ad hoc" assistance in the case of catastrophic event are defined.

The Agricultural payment agency (APA) provides, except for Direct payments, the additional support for small and medium-sized enterprises operating in primary agricultural sector in the form of State Aid. The support is provided for the primary production, food, forestry and fisheries in the form of State Aid and De Minimis aid (f. e. supporting participation of breeders and growers on exhibitions, wage subsidy for disadvantage 
employees, breeding records, control of efficiency of animal breeding value, support in the forestry for non-productive activities). The State Aid is rather development-oriented, than risk managing. In 2018, the APA provided the state aid and de minimis aid in total amount of 4.378 mill $€$, from which $52 \%$ is the support for forestry ( 2.3 mill $€$ ). In comparison to previous years 2014-2018, the volume of provided funds does not differ significantly (each year around 4 mill $€$ ), but the number of received applications has an increasing tendency. Overview of provided state aid and de minimis aid in years $2014-2018$ is shown in Fig. 2.

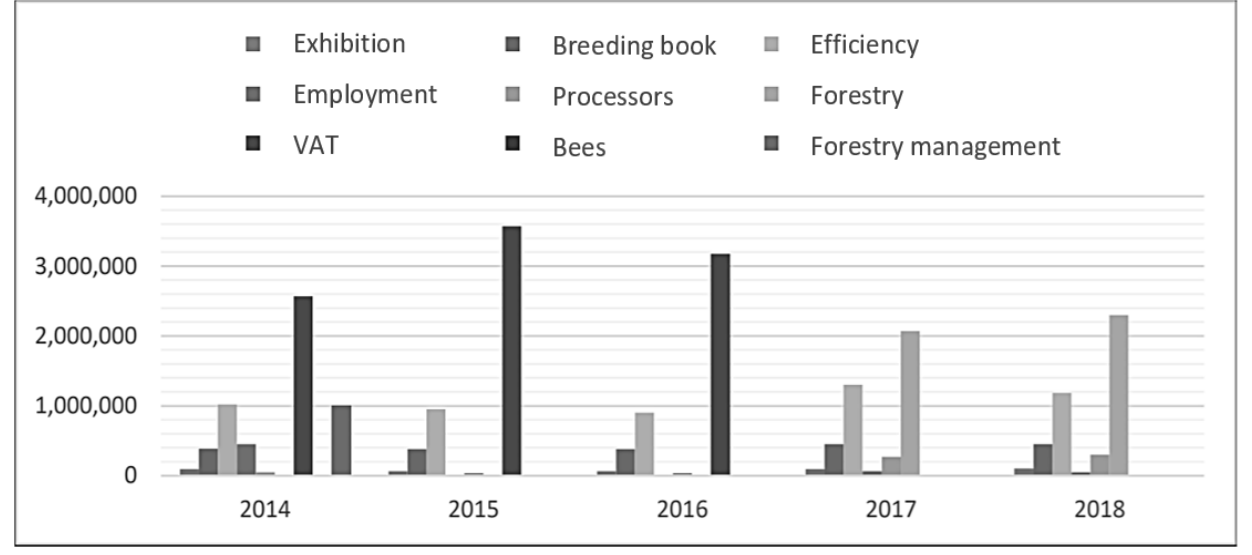

Fig. 2. State aid and aid de minimis

Source: APA 2018, added by authors

The public support of crop insurance in Slovakia provides the Agricultural Paying Agency in accordance with Act no. 71/1967 Coll. and of Act no. 280/2017 Coll.

For the support can apply the entrepreneur or legal entity that uses a registered winegrowing area in the territory of the Slovak Republic in accordance with $\S 8$ para. 3 of Act no. 313/2009 Coll. It means the support is sectoral-based, limited to the vineyards.

Aid for crop insurance of vineyard may be used to cover damages of crops caused by adverse climatic events which can be assimilated to natural disasters; other adverse climatic events; animals, vine diseases or pest infestations. The smallest continuous wine-growing area for which crop insurance aid may be granted is 0,1 ha. The amount of support is calculated based on the actual costs, which were proved by supporting documents insurance contracts, documents on premium payments etc. The insurance support can be provided up to a maximum of:

- $80 \%$ of the paid annual premium, if the subject of the insurance contract is crop insurance against damage caused by an adverse weather event that can be compared to a natural disaster,

- $50 \%$ of the paid annual premium, if the subject of the insurance contract is insurance against damage to crops caused by other adverse climatic event, animals, vine disease, pest infestation.

The applications for support have been available since 2014, and in the year 2015, first 146.8 thous. $€$ were contributed for farmers' crop insurance premium. In 2016, under the support measures of vineyard insurance, 214 thous. $€$ were granted. The interest for the public insurance support of vineyards increased in 2017 and 2018. In 2017, 45 applications with the amount of 298.5 thous. $€$ were approved and in the 2018, 50 applications in the total amount of 315.9 thous. $€[25]$. 


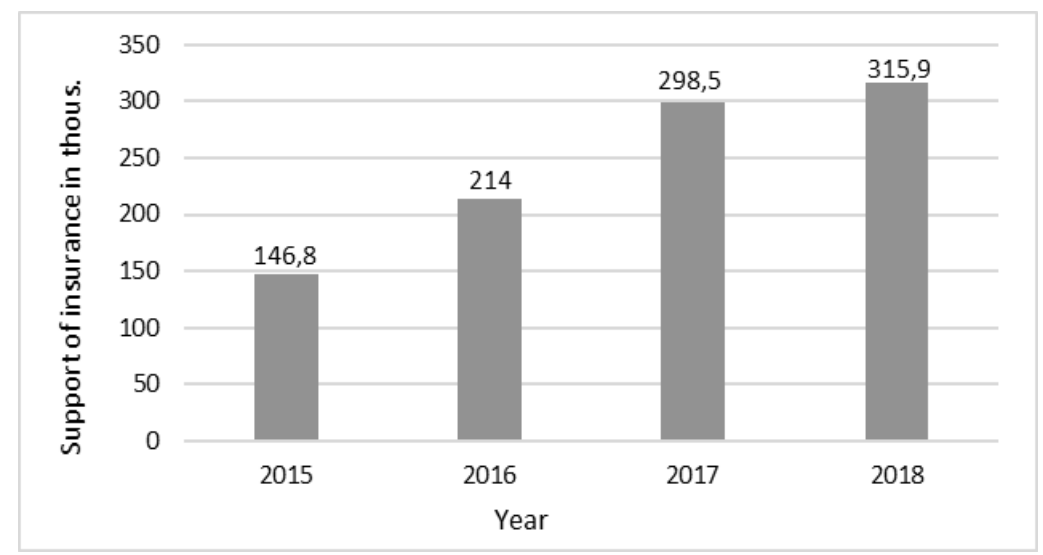

Fig. 3. Support of crop insurance for vineyards in Slovakia, in thous. EUR Source: Green report 2018 (Ministry of Agriculture and Rural Development), own processing

On one hand, we can conclude that the use of insurance support is a positive first step towards implementation of risk management tools. However, the support stays on the sectoral basis and is hardly insufficient, in comparison to the possibilities offered from CAP programme. Also, the awareness and knowledge of farmers about risk management tools is very low in Slovakia.

\section{Conclusion}

Risk management in agriculture includes number of strategies, policies and tools at farm and national level, that may prevent farmers from agricultural risks or respond to crises. An ambition of the recent CAP reform is to increase the focus on risk management in agriculture. In the paper we evaluate the CAP risk management tools from the Pilar II: insurance premiums, mutual funds and income stabilisation tool. Only very low number of Member states have implemented any of these tools since their introduction in 2014 (IST none country). It is mainly caused by the of number of constraints and shortcomings in their guidelines.

The Omnibus Regulation from 2018 is addressed to some of these obstacles to facilitate uptake and implementation. A sector-specific IST has been added to the toolkit, targeting farmers of a specific sector by a drop of income. All compensation rates (thresholds) have been changed from $30 \%$ to $20 \%$. Moreover, indexes can be used to calculate the annual loss of income of the farmer (both general and sector-specific ISTs). Finally, in the case of insurance support and mutual funds, aid intensity rates have been increased from $65 \%$ to $70 \%$. In addition, the Regulation allows the subsidising of 'administrative costs of setting up the mutual fund' and 'the amounts paid by the mutual fund as financial compensation' (Reg. 8314/2017). It is still uncertain, how much these measures will facilitate the development of risk management on the national levels.

In Slovakia, the agricultural risks are mainly managed with the commercial insurance, that do not sufficiently cover all risks and damages. In the case of catastrophic damages and special events, there exist the Ad hoc support from state budget and support of insurance premium for vineyards. The majority of farmers cover their income losses with the direct payments, which provide a stable form of income for farmers regardless of market conditions, rather than with risk management tools. Therefore, there is a long way for Slovak agriculture to learn and establish risk management concept at the national and farm level. 
This paper was supported by the project VEGA: Impact of the Common Agricultural Policy on the mitigation of income risk in Slovak agriculture and factors determining the level of risk of agricultural companies. Project registration number 1/0338/18.

\section{References}

1. Hardaker, J. B., Lien, G., Anderson, J. R., Huirne, R. B. (2015). Coping with risk in agriculture: Applied decision analysis. CABI.

2. Huirne, R. B., Meuwissen, M. P., Hardaker, J. B., Anderson, J. R. (2000). Risk and risk management in agriculture: an overview and empirical results. International Journal of Risk Assessment and Management, 1(1-2), 125-136.

3. OECD. (2009). Managing Risk in Agriculture: A Holistic Approach. Paris: OECD Publishing.

4. Tangermann, S. (2011). Risk management in agriculture and the future of the EU's Common Agricultural Policy. ICTSD Programme on Agricultural Trade and Sustainable Development (Issue Paper 34). Geneva.

5. Cordier, J. (2014). Comparative analysis of risk management tools supported by the 2014 Farm Bill and the CAP 2014-2020. IP/B/AGRI/IC/2014-044. Strassburg: Parlement Européen.

6. Meraner, M., Finger, R. (2019). Risk perceptions, preferences and management strategies: evidence from a case study using German livestock farmers. Journal of Risk Research, 22(1), 110-135.

7. European Commission (2017). Modernising and simplifying the CAP. Background Document Economic challenges facing EU agriculture. Brussel: European Comission.

8. De Rosa, M., McElwee, G., Smith, R. (2019). Farm diversification strategies in response to rural policy: A case from rural Italy. Land Use Policy, 81, 291-301.

9. Meuwissen, M. P., Van Asseldonk, M. A., Huirne, R. B. (2008). Income stabilisation in European agriculture: design and economic impact of risk management tools. Wageningen Academic Publishers.

10. Cordier, J., Santeramo, F. (2020). Mutual funds and the Income Stabilisation Tool in the EU: Retrospect and Prospects. EuroChoices, 19(1), 53-58.

11. Vera, A. C., Colmenero, A. G. (2017). Evaluation of risk management tools for stabilising farm income under CAP 2014-2020. Economía agraria y recursos naturales, 17(1), 3-23.

12. Meuwissen, M. P., Assefa, T. T., van Asseldonk, M. A. (2013). Supporting insurance in European agriculture: Experience of mutuals in the Netherlands. EuroChoices, 12(3), 10-16.

13. Meuwissen, M.P.M., Mey, Y.d., Van Asseldonk, M. (2018). Prospects for agricultural insurance in Europe. Agricultural Finance Review, 78(2), 174-182.

14. Pigeon, M., de Frahan, B. H., Denuit, M. (2014). Evaluation of the EU proposed farm income stabilisation tool by skew normal linear mixed models. European Actuarial Journal, 4(2), 383-409.

15. European Commission. (2013). Regulation (EU) No 1305/2013 of the European Parliament and of the Council of 17 December 2013 on support for rural development by the EAFRD and repealing EC No 1698/2005. Retrieved from : https://eurlex.europa.eu/legal-content/EN/TXT/?uri=celex\%3A32013R1305 
16. Tropea, F. (2016). New income stabilization tools and price volatility in agricultural markets, European Parliamentary Research Services. Brussels: EPRS.

17. Vilhelm, V., Namali Gouri Boyinova, S., Špička, J. (2018). Comparison of Risk Management Tools Under the CAP of the EU, the US Farm Bill and in the Czech Agriculture. Proceedings of the Common Agricultural Policy of the European Unionthe present and the future, EU Member States point of view, 73.1 Monographs of Multi-Annual Programme (pp. 116-124). Warsaw: Institute of Agricultiral and Food economics.

18. European Commission. (2013). Regulation (EU) No 1305/2013 of the European Parliament and of the Council of 17 December 2013 on support for rural development by the EAFRD and repealing EC No 1698/2005. Retrieved from : https://eurlex.europa.eu/legal-content/EN/TXT/?uri=celex\%3A32013R1305

19. European Commision (2017, October). Study on Risk Management in EU Agriculture. Retrieved from: https://op.europa.eu/sk/publication-detail/-/publication/5a935010af78-11e8-99ee-01aa75ed71a1

20. European Commission (2017, December 11). Summary of main changes introduced to the four basic regulations of the CAP through the Omnibus regulation. Retrieved from : https://ec.europa.eu/agriculture/capoverview/summary-changes-omnibus_en.pdf

21. Santeramo, F.G. (2018). Imperfect information and participation in insurance markets: evidence from Italy. Agricultural Finance Review, 78(2), 193-194.

22. Zubor-Nemes, A., Fogarasi, J., Kemény, G. (2018). Farmers' responses to the changes in Hungarian agricultural insurance system. Agricultural Finance Review, 78(2), 275 288.

23. El Benni, N., Finger, R., Meuwissen, M. P. (2016). Potential effects of the income stabilisation tool (IST) in Swiss agriculture. European Review of Agricultural Economics, 43(3), 475-502.

24. Chrastinová, Z., Masár, I., Weldesenbet, T. (2017). Agricultural production risks and their solutions in Slovakia. In J. Goral \& M. Wigier (Eds.), Risk in the food economytheory and practice (pp. 149-165). Warsaw: Instytut Ekonomiki Rolnictwa i Gospodarki Żywnościowej.

25. MPSR (2019, December 20). Správa o polnohospodárstve a potravinárstve v SR za rok 2018 (ZELENÁ SPRÁVA) Retrieved from : https://mpsr.sk/zelena-sprava2019/122---14968/ 